\title{
Customs examination of intellectual property items in international economic activity
}

\author{
Olga Ergunova \\ Department of Foreign Economic Activity \\ Ural State University of Economics \\ Yekaterinburg, Russia \\ ergunova-olga@yandex.ru
}

\author{
Viktor Kovalev \\ Department of Foreign Economic Activity \\ Ural State University of Economics \\ Yekaterinburg, Russia \\ vicko@yandex.ru
}

\author{
Viktor Blaginin \\ Department of Regional, Municipal Economy \\ Ural State University of Economics \\ Yekaterinburg, Russia \\ geschenke777@mail.ru
}

\begin{abstract}
The article is devoted to various aspects of examination, as an integral part of customs control, aimed at ensuring the protection of intellectual property items in international economic activity, as well as assessing the economic damage caused to the right holder by violating trademark rights. Particular attention is paid to the study of examination of the "Angry Birds" trademark in conducting foreign trade transactions. Besides, the economic damage, caused to the right holder by violation of trademark rights, is calculated.
\end{abstract}

Keywords- intellectual property, customs examination, international economic activity.

\section{INTRODUCTION}

Every year, the issues of intellectual property protection take on increasingly great importance in Russia. One of the most popular items of intellectual property is a trademark, that is a mark to identify the product. As it is known, the scale of counterfeit sales in Russia is huge. Low-quality fake products, marked with counterfeit well-known and little-known trademarks, including Russian ones, are coming to Russia from all over the world.

According to evaluation of International Chamber of Commerce, ICC, "the global volume of counterfeit products in 2015 was 1.7 trillion US Dollars or more than $2 \%$ of the global volume of produced goods".

In 2015, customs authorities of the Russian Federation initiated 1040 cases (1 270 administrative cases in 2014) in the sphere of intellectual property protection. 1011 administrative cases (1 234 administrative cases in 2014) were initiated under Article 14.10 of AOC RF (illegal use of trademark) and 29 administrative cases (36 administrative cases in 2014) under Part 1 Article 7.12 of AOC RF (violation of intellectual property and associated rights) [2,3]. In 2015 customs authority found out more than 18.1 million units of counterfeit products (in 2014 - more than 9.5 million units of counterfeit products).

As a result of the identified cases of goods transfer with the signs of violation of intellectual property rights by customs authorities in 2015, the damage to the amount of 3.9 billion rubles (in 2014 - more than 2.4 billion rubles) that could have been inflicted to IPR holders was prevented.

Intellectual property is divided into two categories:

- Industrial property includes patents of inventions, trademarks, industrial samples and geographical indications.

- Copyright includes literary works (for example, novels, poems, and pieces), motion pictures, music, pieces of art (for example, drawings, artistic paintings, photographs and sculptures) and architectural designs. Associated rights include the rights of performers for their works, rights of producers of phonograms for their records and rights of broadcasting agencies for radio and TV programs.

The results of creative and intellectual activity, the rights for which are granted to certain persons by national legislation and international treaties, are called intellectual property items. Intellectual property items are the results of creative and intellectual activity, which are legally protected.

The list of intellectual property items is provided in Article 1225 of Civil Code of the Russian federation (Table 1).

This list of the results of intellectual activity and means of individualization is exhaustive. This means that other items will not be legally protected[4,5].

According to Article 1226 of CC RF, there are intellectual rights for intellectual property items, which includes property rights, personal nonproperty rights and other rights (figure 1).

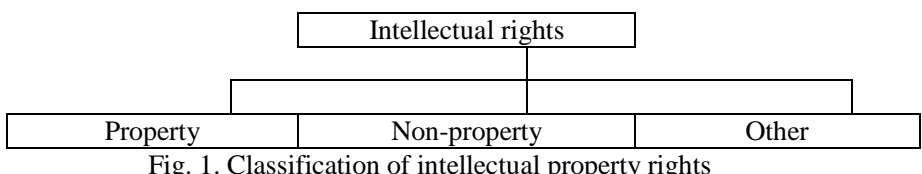

Exclusionary right is the property right, which is characterized by a limited period of its validity, after which intellectual property items can be freely used by other persons. Holder of such a right can, at his own discretion, authorize or prohibit other persons to use the result of his intellectual 
activity. Personal nonproperty rights are always remained with the author, are not transferred, inherited and are permanently protected.

TABLE I. List of intellectual property objects

\begin{tabular}{|c|c|c|}
\hline \multirow{6}{*}{ 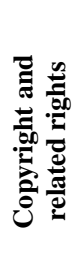 } & \multirow{2}{*}{ Copyright objects } & works of science, literature, art \\
\hline & & computer programs \\
\hline & \multirow{4}{*}{$\begin{array}{l}\text { Objects of copyright- } \\
\text { related }\end{array}$} & databases \\
\hline & & performance \\
\hline & & phonograms \\
\hline & & $\begin{array}{l}\text { messages on the air or by cable of } \\
\text { radio or television programs }\end{array}$ \\
\hline \multirow{10}{*}{ 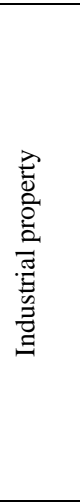 } & \multirow{3}{*}{ Objects of the patent law } & invention \\
\hline & & useful models \\
\hline & & industrial designs \\
\hline & $\begin{array}{l}\text { Object of the right to } \\
\text { selective achievements }\end{array}$ & breeding achievement \\
\hline & $\begin{array}{l}\text { Object of the right to the } \\
\text { topology of integrated } \\
\text { microcircuits }\end{array}$ & topology of integrated circuits \\
\hline & $\begin{array}{l}\text { Object of the right to } \\
\text { secrets of production } \\
\text { (know-how) }\end{array}$ & secrets of production (know-how) \\
\hline & \multirow{4}{*}{$\begin{array}{l}\text { Objects of rights to means } \\
\text { of individualization }\end{array}$} & firm names \\
\hline & & trademarks and service marks \\
\hline & & appellations of origin of goods \\
\hline & & commercial designations \\
\hline
\end{tabular}

It is important to note that "the period for validity of exclusionary right for the result of intellectual activity or for the mean of individualization, procedure for calculation this period, grounds and procedure for its extension, as well as grounds and procedure for termination of exclusionary right prior to the expiration of the period" is regulated by Part 4 of CC RF. According to Article 1477 Part 4 of CC RF, trademark is a designation that serves to individualize the goods of legal entities or individual entrepreneurs. In other words, a trademark is a symbol that can be placed on the product itself, as well as on its packaging or accompanying documents, and which replaces the name of the manufacturer of the goods. This symbol distinguishes the goods of certain legal entities or individuals from the homogeneous goods of others. In terms of their expression there are "word, design, three-dimensional, combined and other trademarks". Also, the trademark can be registered in any color or color combination. In addition to the listed types of trademarks, "other designations of goods and services, in particular sound, light, olfactory and other designations" are allowed to be registered. However, at present such registration is not applied in Russian practice [6].

The right for trademarks is "one of types of intellectual property items, and refers to the rights "for means of individualization of legal entities, goods, works, services, enterprises and information systems" (Chapter 76 of CC RF).

The force of exclusionary rights for the means of individualization of legal entities (except for FIFA), goods, works, services, which have received legal protection in the Russian Federation until the day of entry into force of Federal Law No. 108-Ф3 of 07.06.2013 and containing the symbols of sports competitions, exclusionary rights to which belongs to FIFA at the time of registration of said means of individualization, is suspended until December 31, 2018 (Federal Law No. 108-Ф3 of 07.06.2013).
Let us consider the features of customs examination aimed at ensuring protection of intellectual property items in the implementation of international economic activity. When carrying out international economic activity in accordance with the Customs Code (CC) of the Customs Union (CU), this examination is "the organization and conducting of studies carried out by customs experts and (or) other experts using special and (or) scientific knowledge to solve problems in the field Customs regulation".

According to purposes and objectives, it is divided into identification, trade, materials, technological, criminalistic and other examinations. There are also other classifications, which are specified in CC of CU and are listed in Table 2.

TABLE II. Types of examinations [1]

\begin{tabular}{|l|l|l|}
\hline \multicolumn{1}{|c|}{ Criteria } & \multicolumn{1}{c|}{$\begin{array}{c}\text { Types of } \\
\text { examination }\end{array}$} & \multicolumn{1}{c|}{ Characteristics } \\
\hline \multirow{4}{*}{$\begin{array}{l}\text { The number } \\
\text { of experts } \\
\text { involved }\end{array}$} & Single & It is carried out by one expert \\
\cline { 2 - 3 } & Commission & $\begin{array}{l}\text { It is carried out by a commission of } \\
\text { experts of one qualification }\end{array}$ \\
\cline { 2 - 3 } & Integrated & $\begin{array}{l}\text { It is conducted by a commission of experts } \\
\text { of various qualifications, with each expert } \\
\text { signing only his part of the conclusion }\end{array}$ \\
\cline { 2 - 3 } $\begin{array}{l}\text { Priority of } \\
\text { the } \\
\text { examination }\end{array}$ & Additional & $\begin{array}{l}\text { It is conducted at the request of the } \\
\text { customs body for the study of objects, } \\
\text { samples and samples }\end{array}$ \\
\cline { 2 - 3 } & $\begin{array}{l}\text { It is carried out if any new circumstances } \\
\text { are revealed }\end{array}$ \\
\hline Repeated & $\begin{array}{l}\text { It is conducted when the declarant or } \\
\text { customs body disagrees with the } \\
\text { conclusion of the initial or additional } \\
\text { examination by a commission of } 2 \text { or more } \\
\text { customs experts, except for those who } \\
\text { have already conducted this examination. }\end{array}$ \\
\hline
\end{tabular}

The procedure for commissioning of examination is specified in Article 138, and also it is captured in the decision of CU Commission № 258 of May 20, 2010, according to which the examination (as well as materials, documents, samples, needed for its conducting) is entrusted to the customs authorities, customs experts or experts of other authorized organizations. At the same time, they are allowed to be modified, destroyed partially or completely [7].

The form of the decision on the commissioning of customs examination is established by the legislation of the Member States of the Customs Union. In the Russian Federation, the form of the decision was established by Order No. 396 of the Federal Customs Service of Russia of February 25, 2011 "On approval of the form of the decision on the commissioning of a customs examination, the form of the customs expert's (expert's) conclusion, the procedure for collection of samples of goods for customs examination and the suspension of the customs examination".

The Order of Russian Agency for Patents and Trademarks of 31.12.2009 approved methodic recommendations for conduction of examinations of intellectual property items: on the test of applied trademarks for the sameness and similarity and on the test of homogeneity of goods and services, No. 197 and No.198 respectively [8].

These recommendations guarantee implementation of provisions of Part 4 of the Civil Code of RF in the sphere of 
the rights for trademark and service mark. They are developed principally for the experts and specialists of the Federal Service for Intellectual Property and subordinate organizations. Questions for determination of similarity of various types of symbols and characteristics for homogeneity of goods are in Tables 3, 4 .

TABLE III. Questions for determining the similarity of different types of notation [8].

\begin{tabular}{|c|c|c|}
\hline Type & Compare with & Tags \\
\hline $\begin{array}{l}\text { Verbal } \\
\text { notation }\end{array}$ & $\begin{array}{c}-\quad \text { with verbal symbols } \\
\text { - with combined notation, } \\
\text { whose composition includes } \\
\text { verbal elements }\end{array}$ & $\begin{array}{cc}- & \text { sound (phonetic) } \\
- & \text { graphic (visual) } \\
- & \text { semantic (semantic) }\end{array}$ \\
\hline $\begin{array}{l}\text { Pictorial } \\
\text { and } \\
\text { volumetr } \\
\text { ic } \\
\text { notation }\end{array}$ & $\begin{array}{c}-\quad \text { with pictorial notation } \\
-\quad \text { with volumetric notation } \\
-\quad \text { with combined notation, } \\
\text { in the composition of which } \\
\text { there are pictorial or } \\
\text { volumetric elements }\end{array}$ & $\begin{array}{c}\text { - } \\
\text { presence or absence of } \\
\text { symmetry } \\
-\quad \text { semantic meaning } \\
-\quad \text { type and nature of } \\
\text { images (naturalistic, stylized, } \\
\text { caricature, etc.) } \\
\text { - combination of colors } \\
\text { and tones }\end{array}$ \\
\hline $\begin{array}{l}\text { Combin } \\
\text { ed } \\
\text { designati } \\
\text { ons }\end{array}$ & $\begin{array}{c}\text { with combined notation } \\
-\quad \text { with those types of } \\
\text { designations that are part of } \\
\text { the verified combined } \\
\text { designation as elements }\end{array}$ & $\begin{array}{c}\text { Signs for verbal, pictorial } \\
\text { and volumetric notation in } \\
\text { the aggregate }\end{array}$ \\
\hline
\end{tabular}

TABLE IV. Characteristics of goods homogeneity.

\begin{tabular}{|l|l|}
\hline \multicolumn{1}{|c|}{ Basic } & \multicolumn{1}{c|}{ Auxiliary } \\
\hline \multirow{2}{*}{ Type of goods } & $\begin{array}{l}\text { Conditions for the sale of goods (including } \\
\text { a common place of sale, sale through a } \\
\text { retail or wholesale network) }\end{array}$ \\
\hline $\begin{array}{l}\text { Functional purpose of goods } \\
\text { (scope and purpose of } \\
\text { application) }\end{array}$ & $\begin{array}{l}\text { Circle of consumers (consumer goods and } \\
\text { goods for industrial and technical } \\
\text { purposes) }\end{array}$ \\
\hline $\begin{array}{l}\text { The type of material from } \\
\text { which the goods are } \\
\text { manufactured }\end{array}$ & Consumer properties \\
\cline { 2 - 2 } & Duration / short-term use of goods \\
\cline { 2 - 2 } & The cost of goods (expensive or cheap) \\
\hline
\end{tabular}

In the modern world economy, integration processes occur at two levels: global and regional. Since the beginning of the 20th century, these processes have received considerable acceleration. As a rule, regional initiatives are even wider than global. In this case, speaking about global integration, the authors mean international organizations, in particular the World Trade Organization (WTO), and under regional processes they mean regional unions or in other words, regional trade agreements, as WTO calls it [9]. The WTO was established in 1995 and is the successor to the General agreement on tariffs and trade. It is an international organization defining the rules of trade at a global level.

\section{RESEARCH METHODS}

As an example, let us consider the examination of the "ANGRY BIRDS" trademark in international trade transactions using the documents and samples of goods provided by the Yekaterinburg Customs. The following questions were posed to the expert:
- Are provided samples of goods, having symbols, illustrated on fig.5, "ANGRY BOIDS", 120 pcs., homogeneous to the goods, for individualization of which the following trademarks are registered as international: ANGRY BIRDS, with an indication in RF under №№ 1086866, 1091303 (hereinafter referred to as TM)?

- $\quad$ Are symbols of TM used on the provided samples of abovementioned goods?

- Are provided abovementioned samples of goods, having symbols: ANGRY BOIDS, quantity 120 pcs (manufacturer is "ESSA TOYS TRADING CO.,LTD" (China) homogeneous and identical or confusingly similar to the goods, for individualization of which abovementioned TM are registered?

In order to settle raised questions examination was conducted, using phonetic, graphical and semantic analysis.

Examination and opening of packaging was carried out in mixed lighting (daylight and lamplight), in the room No. 4 at the address: Yekaterinburg, ul. Zavokzalnaya, 40.

An item, subjected to examination, was received in 1 (one) polymeric package with the stamp, ensuring the integrity of packaging, having the name of customs authority (Yekaterinburg Customs), descriptive information (item shoe bag), signatures of the customs authority official, witnesses and a person, who gave samples, as well as 1 (one) stamp impression of round form "Administrative Investigations Department".

According to Part 1 Article 1515 of the Civil Code of RF goods, labels, packaging of goods, which have illegal trademarks or confusingly similar symbols, are counterfeit goods. According to Resolution of the Plenum of the Supreme Arbitration Court of the Russian Federation No. 11 of 17.02.2011, "such violations as the introduction of goods, as well as labels, packaging, documentation of which contains illegal reproduction of the means of individualization, into civil circulation on the territory of the Russian Federation, as well as import to the Russian Federation of such goods with the aim of introducing it into civil circulation on the territory of the Russian Federation should be regarded as the illegal use of a trademark".

According to the data, received from the legitimate sources of information, trademark №1086866 is protected on the territory of the Russian Federation in accordance with the applicable legislation. The holder of this trademark is Rovio Entertainment Ltd, Keilaranta 17 C FI-02150 Espoo (FI).

Examined symbol is located on child bag, provided for examination, and trademark, which belongs to Rovio Entertainment Ltd, Keilaranta 17 C FI-02150 Espoo (FI) №1086866 is used for the goods of 18 class of International Classification of Goods and Services - travelling trunks, suitcases, travel bags, leather bags for travel sets, travel bags for clothing, handbags, knapsacks, beach bags, shopping bags, field bags, attaché cases for documents, etc.

Thus, the goods of 18 class of International Classification of Goods and Services as per certificate №1086866 and the sample of the good, provided for examination, are 
homogeneous, as according to one of the basic characteristics of homogeneity (purpose of the good) the goods have similar purpose of use - storage and transportation of various items, according to age and gender characteristic it is a product for child, the goods have the same conditions for sale (additional characteristic) - sale through distributive networks and shops .

TABLE V. Characteristics of the trademark under investigation $[3,9]$

\begin{tabular}{|l|l|}
\hline \multicolumn{1}{|c|}{ Certificate number } & №1086866 \\
\hline Registration date & 15.04 .2011 \\
\hline Date of expiry of registration & 15.04 .2021 \\
\hline Image of trademark & $\begin{array}{l}\text { Rovio Entertainment Ltd, } \\
\text { Keilaranta 17 C FI-02150 Espoo } \\
\text { (FI) }\end{array}$ \\
\hline Name of legal owner & $\begin{array}{l}03,09,14,16,18,20,21,24,25,27,28,2 \\
9,30,33,34,35,36,38,4143\end{array}$ \\
\hline Classes of ICGS & $\begin{array}{l}\text { Red, burgundy, black, orange, } \\
\text { beige and white }\end{array}$ \\
\hline $\begin{array}{l}\text { Specifying color or color } \\
\text { combination }\end{array}$ & the \\
\hline
\end{tabular}

The customers will connect the use of trademark by another person in relation to the goods of 18 class of International Classification of Goods and Services (bags) with the holder of exclusionary right for trademark.

Compared symbols are considered to be identical, if they are in complete accord, that is they are the same. As a result of the conducted comparative analysis of the symbol applied to the provided sample and trademark No. 1086866, it is established, that they are not identical, since they have visible differences.

Therefore, on the basis of the foregoing, the symbol located on the investigated product (Figure 6, Illustration 3) is confusingly similar to the trademark registered in the International Bureau of the World Intellectual Property Organization (WIPO) under registration number 1086866, as they are generally associated, despite some differences.

\section{RESULTS AND DISCUSSION}

Examined goods do not correspond to original, license products on the following characteristics:

1) The good has no legal notice of the right holder, information on licensee, which manufactured the good, as well as official name of the good;

2) Good appearance does not correspond to the standards of the right holder: in particular, the images of birds differ from original ones.

The company Rovio Entertainment Ltd did not conclude with OOO "UTLK" any contracts for the use of trademarks, in particular, did not grant the rights for import and/or introduction in civil circulation of shoe bags with the specified trademark. Revealing of at least one discrepancy between the examined sample and original products of "Rovio Entertainment Ltd" is a sign of counterfeit. Therefore, there is a discrepancy between the good provided for examination and original products of "Rovio Entertainment Ltd". In addition to it, it is necessary to mention, that the presence of the abovementioned trademark on the examined good misinforms the consumer as to the manufacturer, product quality, etc.

Consequently, the symbol, applied to the examined good, is confusingly similar to the registered trademark of "Rovio Entertainment Ltd". The goods, provided for examination, and goods, for which the trademark of «Rovio Entertainment Ltd» is protected, are homogeneous.

TABLE VI. Study of the trademark under investigation for similarity to the degree of mixing

\begin{tabular}{|c|c|c|}
\hline $\begin{array}{c}\text { Investigated } \\
\text { signs }\end{array}$ & Registered trademark «»» & Designation \\
\hline Appearance & $\begin{array}{l}\text { Graphic stylized image } \\
\text { of a bird, the shape is close } \\
\text { to an oval, close-set eyes } \\
\text { to each other, eyebrows } \\
\text { triangular in shape, short } \\
\text { and thick beak. At the top } \\
\text { of the bird there is a two- } \\
\text { petiolate crest, the tail is a } \\
\text { three-petiolate cap. }\end{array}$ & $\begin{array}{l}\text { Graphic stylized image of the } \\
\text { bird, the shape is close to an } \\
\text { oval, closely set to each } \\
\text { other's eyes, eyebrows } \\
\text { triangular in shape, short and } \\
\text { thick beak. At the top of the } \\
\text { bird there is a two-petiolate } \\
\text { crest, the tail is a three- } \\
\text { petiolate cap. }\end{array}$ \\
\hline \multicolumn{3}{|c|}{ The identities to be compared are the same } \\
\hline $\begin{array}{l}\text { Graphical } \\
\text { (visual) } \\
\text { similarity }\end{array}$ & $\begin{array}{c}\text { Graphic stylized image } \\
\text { of an anthropomorphic } \\
\text { bird. } \\
\text { At the registered trade } \\
\text { mark - birds of a brow are } \\
\text { frowned and the beak is } \\
\text { slightly opened (a mimicry } \\
\text { expresses aggression, } \\
\text { anger, anger). }\end{array}$ & $\begin{array}{l}\text { Graphic stylized image of a } \\
\text { bird. The difference from the } \\
\text { registered trademark lies in } \\
\text { the mimicry of the bird - the } \\
\text { beak is closed, the eyebrows } \\
\text { are not frowned, the } \\
\text { appearance expresses } \\
\text { calmness. }\end{array}$ \\
\hline
\end{tabular}

The comparative designations are similar to the degree of mixing according to a graphic feature

\begin{tabular}{|c|c|}
\hline $\begin{array}{c}\text { Sense } \\
\text { similarity }\end{array}$ & $\begin{array}{c}\text { In both cases, there is an image of an animated character. } \\
\text { The notation is the same. }\end{array}$ \\
\cline { 2 - 3 } Conclusion & $\begin{array}{c}\text { The graphical similarity, external and semantic identity of } \\
\text { the compared notations (the image applied to the product } \\
\text { and registered trademark for the research presented for the } \\
\text { research) can cause an associative connection in the } \\
\text { consumer's mind, as a result of which the consumer can } \\
\text { decide that the goods marked with labels are a product line } \\
\text { of one manufacturer. Thus, taking into account the } \\
\text { foregoing, the comparisons used are similar to a degree of } \\
\text { confusion. }\end{array}$ \\
\hline
\end{tabular}

After completion of examination, the sample of the good was placed in the original package - one polymer package with the stamp ensuring the integrity of packaging, having the signature of the expert and stamp impression "For packages" of Forensic Agency - subdivision of Central Forensic Customs Administration in Yekaterinburg (table 6) and returned to the Yekaterinburg Customs together with the expert's conclusion.

The Arbitration Court of the Sverdlovsk Oblast, consisting of Judge Kiselev Yu.K. and the judge assistant Kachurina A.S., who kept records during the court session, considered in the court session the case upon the application of the Yekaterinburg Customs (hereinafter - the customs) to the 
limited liability company "UTLK" (INN 6671420452, OGRN 1136671010410, hereinafter - the company) on bringing to administrative responsibility.

The customs claims are based on the "files of administrative offence case № 10502000-6344/2015, during investigation of which was established, that the company imported to the customs territory of Customs Union goods shoe bags, made of polyester, article number HYE041602, 120 pcs., having the image of a bird and symbol "ANGRY BOIDS", confusingly similar to the trademark "ANGRY BIRDS” (certificate MP № 1086866, 1091303), belonging to the company "Rovio Entertainment Ltd" (Finland)".

The Court heard the pleadings of the parties' representatives, examined the samples of the disputed good.

Pursuant to case materials, the company "imported into the territory of the Russian Federation the goods - shoe bags made of polyester with the words "ANGRY BOIDS", confusingly similar to the registered trademark "ANGRY BIRDS", and with the image of a bird, confusingly similar to the registered graphic trademark. "At the same time, the goods imported by the company are homogeneous in relation to the goods for individualization of which the abovementioned trademark is registered".

These conclusions are based on the abovementioned expert's opinion, as well as on the direct investigation and assessment by the court of written and material evidence provided by customs.

The company has no permission from the right holder for usage of the said trademark. Thus, the actions of the company are treated as "administrative offense specified in Part 1 Article 14.10 of the Code of Administrative Offenses of the Russian Federation". Under these circumstances, the requirement of the customs to bring a person to administrative responsibility is subject to satisfaction.

Based on Article 167-170, 206 of the Arbitration Procedural Code of the Russian Federation, the Arbitration Court decided to "hold the limited liability company "UTLK" (INN 6671420452, OGRN 1136671010410) administratively liable as specified in Part 1 Article 14.10 of the Code of Administrative Offenses of the Russian Federation and give a fine in the amount of 100000 (one hundred thousand) rubles with the confiscation of the goods containing illegal reproduction of the trademark: child shoe bags (bags) made of polyester, article number HYE041602 in the quantity of 120 pieces, seized by the exemption protocol of 20.10.2015.".

Modern technologies require fast and adequate changes in the legislation on the protection of intellectual property rights, the development of effective economic, legal and organizational-legal methods and models both for investigation of intellectual property infringements (including procedures for assessing the losses of trademark right holders (hereinafter - TM) from counterfeiting), and for the assessment of the level of counterfeit products in the country and in the world. Immaturity of the problem is evidenced by the fact that today in Russia there is no generally accepted methodology for calculating indexes reflecting the scale of counterfeiting in the IP sphere, and also there are no clear rules, standards and methods for assessing the losses of TM rights holders.

According to the applicable legislation property damage (losses) of the right holder, caused by infringement of the rights for trademarks, includes:

costs of the TM right holder, associated with the restoration of infringed right (costs of conducting of various examinations, court and administrative costs, including costs of information search and proof of juridical facts);

- loss in value of rights for trademark caused by infringement of rights (real loss);

- unreceived income of the right holder (or income received illegally by the violator) — loss of expected profit.

To calculate the index, it is necessary to determine the amount of damage, caused to the right holders, (in thousand rubles), by multiplying the quantity of revealed goods (in accounting units) and the price for original goods, containing IPI (both included and not included in Customs Intellectual Property Registry).

The index is calculated (in thousand rubles) by addition of amounts of damage, caused to the right holders, for each revealed in accounting period case of goods transfer with the sign of infringement of rights for IP, according to the following formula (1):

$$
\mathrm{S}=\sum_{\mathrm{i}=1}^{\mathrm{N}} \mathrm{K}_{\mathrm{i}} \cdot \mathrm{P}_{\mathrm{i}}
$$

where $\mathrm{Ki}$ - quantity of revealed goods in accounting units, used in case of sale of goods in the domestic market $(\mathrm{kg}$, pcs., 1, sq. m, etc.);

$\mathrm{Pi}$ - price for original goods (market price for goods, which in comparable circumstances is usually charged in case of their sale in the domestic market and proper use of intellectual property item);

$\mathrm{N}$ - number of cases, when goods with the signs of infringement of the rights for intellectual property were revealed.

The price for original goods is determined on the basis of the data, provided by the right holder, or on the basis of the data, contained in the expert's conclusion on the market price of the goods, or using the information, placed in web-sites of: right holder (legal manufacturer) of the assessed goods; authorized distributors of the manufacturer, well-known big suppliers, who sale assessed goods on the territory of the Russian Federation with consent of the right holder, which contain average prices for goods in the market.

Result index $\mathrm{S}$ is calculated (in thousand rubles) by adjustment of index $\mathrm{S}$ taking into account final and binding within the accounting period court decisions and decisions, made on the administrative offence cases, using the formula (2), specified below:

$$
\mathrm{S}_{\text {total }}=\mathrm{S}-\mathrm{S}_{\mathrm{C}}-\mathrm{S}_{\mathrm{AO}}(2)
$$


where $S_{C}-$ the cost of goods, in respect of which an infringement of intellectual property rights has not been established by a court decision that entered into legal force; in thousand rubles;

$\mathrm{S}_{\mathrm{AO}}$ - the cost of goods, which were the subject-matter of $\mathrm{AO}$ as of the moment of initiation of $\mathrm{AO}$ case, in relation to which the customs authority decided to terminate it, in thousand rubles.

To determine free (market) cost (price) of a good, the following can be used:

1) A cost approach (method), when market cost (price) of goods is determined as the sum of production expenses and average for this sphere profit. For this purpose, standard for such cases, direct and indirect expenses for the production (purchasing) and (or) sale of goods, works or services, expenses for transportation, storage, standard for such case, and other expenses are taken into account.

2) A method of market comparisons based on the selection of identical or like product from the products, introduced in the market. For this purpose, market cost is calculated as average price for like product in the domestic market of the Russian Federation.

It is not possible to determine market cost of the examined good by the cost approach (method), as the customs expert has no necessary information to determine the market cost by the cost approach (method).

The most applicable method to determine market cost (price) of goods for customs purposes is a comparative approach (method) to examination.

The market cost of a good - consumer goods was determined by using the comparative approach (method) of analog comparison of prices for the goods of similar range, freely sold on the territory of the Russian Federation.

As a result of the conducted examination, the average market price for the examined goods, sold in a specific market in a given period of time, is determined.

The calculation of the average cost of similar product on the Russian market, as of 21.09.2015, can be found in Table 7.

TABLE VII. Calculation of the average cost of similar product.

\begin{tabular}{|l|c|c|}
\hline \multicolumn{1}{|c|}{ Source of information } & $\begin{array}{c}\text { Cost for } \\
\text { unit, in } \\
\text { rubles }\end{array}$ & $\begin{array}{c}\text { Average cost } \\
\text { for unit, in } \\
\text { rubles }\end{array}$ \\
\hline http://www.lumna.ru & $\mathbf{6 3 . 3 4}$ & \multirow{2}{*}{} \\
\cline { 1 - 2 } https://www.sima-land.ru & 79.00 & \multirow{2}{*}{$\mathbf{7 0 . 9 2}$} \\
\cline { 1 - 2 } http://delmare-opt.ru & 73.28 & \\
\hline http://allchexol.ru & 65.00 & \\
\hline http://kuz-sp.ru & 74.00 & \\
\hline
\end{tabular}

On the basis of abovementioned, average cost of the product - one child bag, on the Russian market, as of 21.09 .2015 , is 70.92 rubles.

Thus, free (market) cost (price) of the whole goods batch, provided for the examination in the amount of 120 child bags, on the Russian market, as of 21.09.2015, is 8510.40 rubles.
70.92 rubles x 120 pcs. $=8510.40$ rubles.

Report on index calculation should contain information in accordance with Table 8, provided below.

TABLE VIII. Constituents of index S.

\begin{tabular}{|c|c|c|c|c|}
\hline Product name & $\begin{array}{c}\text { Name of } \\
\text { intellectual } \\
\text { property item }\end{array}$ & $\begin{array}{c}\mathbf{K i} \\
\text { (in } \\
\text { accounting } \\
\text { units - pcs.) }\end{array}$ & $\begin{array}{c}\mathbf{P i} \\
\text { (rubles) }\end{array}$ & $\begin{array}{c}\mathbf{K i} \text { * Pi } \\
\text { (rubles) }\end{array}$ \\
\hline $\begin{array}{l}\text { Shoe bags made of } \\
\text { polyester, article } \\
\text { number HYE041602 }\end{array}$ & $\begin{array}{c}\text { "ANGRY } \\
\text { BOIDS" }\end{array}$ & 120 & 70.92 & 8510.40 \\
\hline \multicolumn{2}{|r|}{ Total amount per quarter S (rubles) - 8510.40 rubles } \\
\hline
\end{tabular}

If the damage caused by the illegal use of the trademark "ANGRY BIRDS" (certificates MR No. 1086866, 1091303) is calculated based on the cost of the original products of the company "Rovio Entertainment Ltd" (Finland), then, taking into account the exchange rate as of 21.09.2015, there are the following data.

TABLE IX. Constituents of index $\mathrm{S}$.

\begin{tabular}{|l|c|c|c|c|c|}
\hline \multicolumn{1}{|c|}{$\begin{array}{c}\text { Product } \\
\text { name }\end{array}$} & $\begin{array}{c}\text { Name of } \\
\text { intellectu } \\
\text { al } \\
\text { property } \\
\text { item }\end{array}$ & $\begin{array}{c}\text { Ki } \\
\text { (in } \\
\text { accounti } \\
\text { ng units } \\
- \text { pcs.) }\end{array}$ & $\begin{array}{c}\text { Pi } \\
\text { (US } \\
\text { dollars) }\end{array}$ & $\begin{array}{c}\text { Pi } \\
\text { (rubles) }\end{array}$ & $\begin{array}{c}\text { Ki* Pi } \\
\text { (rubles) }\end{array}$ \\
\hline $\begin{array}{l}\text { Shoe bags } \\
\text { made of } \\
\text { polyester, } \\
\text { article } \\
\text { number } \\
\text { HYE041602 }\end{array}$ & $\begin{array}{c}\text { "ANGRY } \\
\text { BOIDS" }\end{array}$ & 120 & 17.85 & 1171.75 & 140610.52 \\
\hline \multicolumn{2}{|l|}{ Total amount per quarter S (rubles) - 140 610.52 rubles } \\
\hline
\end{tabular}

Thus, it can be concluded that the right holder received a significant damage from counterfeit products as a whole. And, depending on the method of calculation and justification, the results may vary greatly. In the first case, the authors considered damage, which was equal to the income received on the territory of the Russian Federation. This figure was 16.5 times less than the calculation by the principle: the introduction of one unit of counterfeit products into civil circulation is equal to the introduction of one unit of legal products into civil circulation.

In addition to the already calculated real damage and loss of profit, the right holder also incurs other losses. First of all, it is losses from a decline in the market share of the right holder, as a result of replacing its products with counterfeit goods. The decrease in consumer confidence in the products of this trademark, the shortage in license payments, and the increase in advertising costs aimed at eliminating the negative consequences from counterfeiting and others - all this is the consequences of the turnover of counterfeit products, which causes great damage to the right holders.

Summarizing the results of this study, it can be concluded that the problem of counterfeit and fake products requires a comprehensive approach to its solution. The solution of this problem requires not only government legislative interventions, but also the improvement of norms and standards for verification of fake products; optimization of the material and technical resources for examination and identification of goods; strengthening of measures to control the actions of the executive bodies in the sphere of counterfeit 
and falsification of goods; improvement of the procedure for registration and use of brands in trade turnover; use of innovations in packaging and the production of goods to protect against forgery; strengthening interaction between government bodies, local governments, customs and producers in the fight against fake and counterfeit products.

\section{References}

[1] Customs Code of the Customs Union (Annex to the Treaty on the Customs Code of the Customs Union) [Text]: Decision of the Interstate Council of the Eurasian Economic Community of November 27, 2009 No. 17, Collection of Legislation of the Russian Federation, No. 50, 2010.

[2] O. T. Ergunova, V. G. Lizunkov, E. Y. Malushko, V. I. Marchuk, A. Y. Ignatenko, "Forming system of strategic innovation management at high-tech engineering enterprises", IOP Conference Series: Materials Science and Engineering, vol. 177, Article number 012046, 2017.

[3] Federal Service for Intellectual Property: [Electronic resource]. Access mode: http://www.rupto.ru.

[4] V. G. Lizunkov, M. G. Minin, E. Y. Malushko, V. E. Medvedev, "Developing economic and managerial competencies of bachelors in mechanical engineering", SHS Web of Conferences, vol. 28, Article number 01063, pp. 1-5, 2016.

[5] V.G. Lizunkov, V.I. Marchuk, E.A. Podzorova, "Identification of Criteria, Features of Development and Level of Economic and Managerial Competencies of Bachelors in Mechanical Engineering", Procedia - Social and Behavioral Sciences, vol. 206, pp. 388-393, 2016.

[6] M.A. Loshchilova, V.G. Lizunkov, A.V. Zavjyalova, "Professional Training of Mechanical Engineering Bachelors, Based on Network Resources". Procedia - Social and Behavioral Sciences, vol. 206, pp. 399-405, 2015.

[7] E. Malushko, O. Maletina, V. Lizunkov, V. Tsybaneva, "Use of virtual learning system for educating students with disabilities and special needs", SGEM 2016: conference proceedings. BK 1: Psychology And Psychiatry, Sociology And Healthcare, Education Conference Proceedings, Vol I, 2016 [3rd International Multidisciplinary Scientific Conference on Social Sciences and Arts]

[8] Methodological recommendations for verifying the claimed designations for identity and similarity [Electronic resource]: Order of Rospatent of December 31, 2009, No. 197, Federal Service for Intellectual Property. - Access mode: http://www.rupto.ru/

[9] World Intellectual Property Organization: [Electronic resource]. Access mode: http://www.wipo.int/about-ip/ru 